\title{
Peonomies
}

Central European Review of Economics \& Finance

Vol. 28, No. 6 (2018), pp. 5-23

DOI: $10.24136 /$ ceref.2018.028

Received: 17 March 2018. Accepted: 30 October 2018.

Wojciech POLAN ${ }^{1}$

\section{INTRA-INDUSTRY COMPETITIVENESS OF THE EUROPEAN UNION MEMBER STATES BY INDUSTRY IN 2004-2015²}

The article aims to present the results of research into changes in the international competitive position of the European Union Member States in the period 2004-2015 on the basis of analysing the development of particular types of intra-industry trade (IIT) of manufactured goods.

The investigation was based on the IIT share measurement methodology (Grubel, Lloyd 1975) and calculations of types of intra-industry trade (Greenaway, Hine, Milner 1994, 1995). Multilateral IIT indices were computed at the 6-digit $\mathrm{CN}$ code level on the basis of data published by Eurostat.

As part of a larger research project funded by the National Science Centre, this analysis contributes to the assessment of the degree of intra-industry specialisation of the EU Member States and the resulting changes in the international competitive position of the economies covered.

Keywords: intra-industry trade, international competitiveness, EU enlargement.

JEL Classification Codes: F14, F15.

\section{Introductory remarks}

The analysis aimed to answer the following research questions:

1) after 11 years from the most extensive enlargement of the European Union, what was the product composition of the intra-industry trade of the EU-15 in manufactured goods?

\footnotetext{
${ }^{1} \mathrm{MSc}$ - PhD student at the Cracow University of Economics, Department of International Economic Relations. ${ }^{2}$ The publication is a result of the research grant financed by the National Science Centre, decision no. 2015/17/N/HS4/01529.
} 
2) did the changes in the composition of two-way trade in the EU-10 in 2004-2015 follow patterns similar to those observed in the EU-15 and did they have a positive structural dimension?

On account of the volume of the publication required by the Publishing House, this paper only presents the study results for the SITC sections (5 to 8 ) which are classified in the nomenclature in question as manufactured goods and in the period covered accounted for nearly $80 \%$ of the merchandise trade of the EU-25.

The analysis of intra-industry trade in manufactured goods was supplemented with an examination of the composition of trade broken down into groups of products characterised by varying technology intensity.

The composition of intra-industry trade by industry was analysed at the level main SITC categories ${ }^{3}$ :

a) primary commodities:

- food, drinks and tobacco (sections 0 and 1),

- raw materials (sections 2 and 4),

- energy products (section 3),

b) manufactured goods:

- chemicals (section 5),

- other manufactured goods (sections 6 and 8),

- machinery and transport equipment (section 7),

- other (section 9).

Data were aggregated and allocated to specific analytical groups on the basis of source data from the Eurostat database at a low aggregation level of 6-digit $\mathrm{CN}$ codes. The grouping took account of the main methodological assumptions adopted by other researchers for analyses of intra-industry trade (Kawecka-Wyrzykowska et al. 2017, pp. 25-33).

In an examination of particular $\mathrm{CN}$ sections at the country level with a low value of trade flows, even a single major transaction may significantly affect the composition of intra-industry trade in products of the group concerned. In such cases, the focus was on comparing trends in the country structure of trade in the EU-10 and the EU-15.

\section{Composition of intra-industry trade by industry}

Data presented in Tables 1 and 2 and the trends illustrated in Figure 1 served as the basis for analysing the structure of the intra-industry competitiveness of the EU-10 in comparison with the EU-15 at the level of total trade for each of the seven SITC commodity groups.

\footnotetext{
${ }^{3}$ For more on the Standard International Trade Classification see http://ec.europa.eu/eurostat/statistics-explained/index.php/Glossary:Standard_international_trade_classification_(SITC) (retrieved on 01/11/2017).
} 
Table 1. Value and structure of merchandise trade by SITC commodity group in the EU-10 and the EU-15 in 2004 and 2015, broken down into total trade and intra-industry trade

\begin{tabular}{|c|c|c|c|c|c|c|c|c|}
\hline & \multicolumn{4}{|c|}{ Total trade } & \multicolumn{4}{|c|}{ Intra-industry trade } \\
\hline & EU-10 & EU-10 & EU-15 & EU-15 & EU-10 & EU-10 & EU-15 & EU-15 \\
\hline & 2004 & 2015 & 2004 & 2015 & 2004 & 2015 & 2004 & 2015 \\
\hline & \multicolumn{8}{|c|}{ value of trade flows, EUR billion } \\
\hline Food, drinks and tobacco $(0+1)$ & 23.4 & 99.3 & 360.7 & 709.4 & 3.1 & 18.2 & 79.0 & 156.8 \\
\hline Raw materials $(2+4)$ & 14.4 & 37.9 & 138.6 & 244.7 & 1.6 & 5.3 & 21.9 & 39.1 \\
\hline Energy products (3) & 30.2 & 82.8 & 320.6 & 605.1 & 2.6 & 14.1 & 43.0 & 100.8 \\
\hline Chemicals (5) & 43.2 & 124.2 & 687.9 & 1170.1 & 6.3 & 33.0 & 230.2 & 397.7 \\
\hline Other manufactured goods $(6+8)$ & 151.0 & 350.2 & 1314.1 & 1993.6 & 37.8 & 106.0 & 413.9 & 635.0 \\
\hline Machinery and transport equipment (7) & 178.8 & 534.0 & 1824.5 & 2858.3 & 53.8 & 172.3 & 700.2 & 993.0 \\
\hline Other (9) & 1.8 & 1.2 & 11.8 & 78.3 & 0.4 & 0.4 & 1.8 & 12.5 \\
\hline \multirow[t]{2}{*}{ Total } & 442.9 & 1229.6 & 4658.0 & 7659.5 & 105.7 & 349.3 & 1490.0 & 2335.7 \\
\hline & \multicolumn{8}{|c|}{ structure, share in $\%$} \\
\hline Food, drinks and tobacco $(0+1)$ & 5.3 & 8.1 & 7.7 & 9.3 & 3.0 & 5.2 & 5.3 & 6.7 \\
\hline Raw materials $(2+4)$ & 3.3 & 3.1 & 3.0 & 3.2 & 1.5 & 1.5 & 1.5 & 1.7 \\
\hline Energy products (3) & 6.8 & 6.7 & 6.9 & 7.9 & 2.5 & 4.0 & 2.9 & 4.3 \\
\hline Chemicals (5) & 9.8 & 10.1 & 14.8 & 15.3 & 6.0 & 9.4 & 15.5 & 17.0 \\
\hline Other manufactured goods $(6+8)$ & 34.1 & 28.5 & 28.2 & 26.0 & 35.8 & 30.3 & 27.8 & 27.2 \\
\hline Machinery and transport equipmer & 40.4 & 43.4 & 39.2 & 37.3 & 50.9 & 49.3 & 47.0 & 42.6 \\
\hline Other (9) & 0.4 & 0.1 & 0.3 & 1.0 & 0.3 & 0.1 & 0.1 & 0.5 \\
\hline Total & 100.0 & 100.0 & 100.0 & 100.0 & 100.0 & 100.0 & 100.0 & 100.0 \\
\hline
\end{tabular}

Source: Eurostat, EasyComext, http://epp.eurostat.ec.europa.eu/newxtweb [retrieved on 13/03/2017]. Own study.

Table 2. Dynamics of merchandise trade by SITC commodity group in the EU-10 and the EU-15 in 2004 and 2015 (2004=100\%)

\begin{tabular}{|l|c|r|r|r|r|r|}
\hline \multirow{2}{*}{} & \multicolumn{2}{|c|}{ Total trade } & \multicolumn{2}{c|}{ Intra-industry trade } & \multicolumn{2}{c|}{ Inter-industry trade } \\
\cline { 2 - 7 } & EU-10 & \multicolumn{1}{|c|}{ EU-15 } & EU-10 & EU-15 & EU-10 & EU-15 \\
\hline food, drinks and tobacco (0+1) & 324 & 97 & 480 & 98 & 300 & 96 \\
\hline raw materials (2+4) & 163 & 77 & 239 & 78 & 154 & 76 \\
\hline energy products (3) & 174 & 89 & 434 & 134 & 149 & 82 \\
\hline chemicals (5) & 187 & 70 & 423 & 73 & 147 & 69 \\
\hline other manufactured goods (6+8) & 132 & 52 & 180 & 53 & 116 & 51 \\
\hline machinery and transport equipment (7) & 199 & 57 & 220 & 42 & 189 & 66 \\
\hline Other (9) & -32 & 565 & -2 & 596 & -39 & 560 \\
\hline Total & 178 & 64 & 230 & 57 & 161 & 68 \\
\hline
\end{tabular}

Source: Eurostat, EasyComext, http://epp.eurostat.ec.europa.eu/newxtweb [retrieved on 13/03/2017]. Own study. 
30

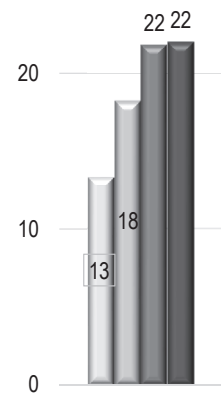

food, drinks and tobacco $(0+1)$

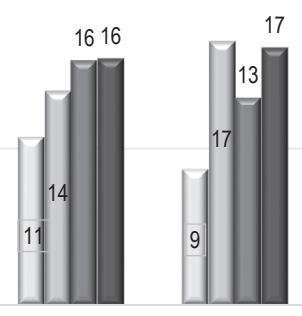

(3)

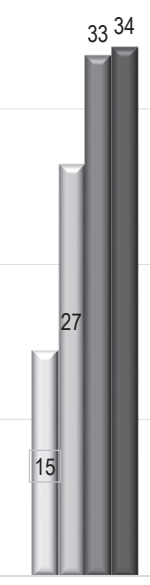

chamicals (5)

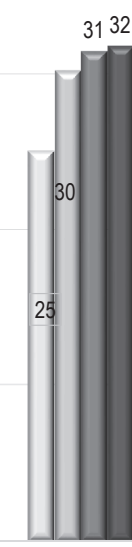

other manufactured goods $(6+8)$

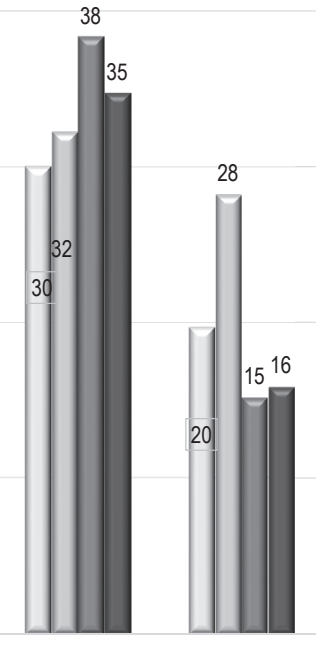

machinery and other (9) transport equipment (7)

Figure 1. Shares of intra-industry trade in specific types of trade in the SITC commodity groups covered, in the EU-10 and the EU-15 in 2004 and 2015 (IIT indices in \%)

Source: Eurostat, EasyComext, http://epp.eurostat.ec.europa.eu/newxtweb [retrieved on 13/03/2017]. Own study.

Detailed trends analysed for each of the seven commodity groups SITC covered are presented in sub-chapters describing specific groups.

\section{Machinery and transport equipment}

In the period in question, the SITC commodity group (section 7), i.e. machinery and transport equipment, accounted for the largest part of foreign trade in the EU-1 $5^{4}$. In 2015 , it was as much as $37.3 \%$ of the value of the total trade of the EU-15 (cf. Table 1). In 2004 , the respective share was $39.2 \%$. The role of the group in total trade slightly declined in the period in question. It is also reflected in the low dynamics of the trade value - a rise from EUR 1.82 trillion to EUR 2.85 trillion meant a considerable increase in value but - in comparison with the other groups - the growth rate was relatively low, at a mere $57 \%$ (see Table 2).

As regards the intra-industry trade of the EU-15, in 2004-2015 the SITC commodity group (7) played the greatest role. In 2015, machinery and transport equipment accounted for $42.6 \%$ of total two-way trade in the EU-15. In 2004, the respective share

\footnotetext{
${ }^{4}$ The largest exporting firms in the EU-15 operated in the industry concerned. For Germany, those included: VW, Daimler, BMW, Continental, Siemens, KHS. For France: Renault, Michelin, Saint-Gobain, Transityre. As regards Spain and Italy, those comprised: Ferrovial, Abertis, Nemak, Telefonica. Fiat and Pirelli. For more cf. www.worldstopexports.com
} 
was $47 \%$. The value of trade increased from EUR 700 billion to EUR 993 billion (by $42 \%$ ). The comparison of the growth rate with those for the other commodity groups shows that in the years covered enterprises from the EU-15 developed IIT more quickly in commodity groups other than machinery and transport equipment (cf. Table 1).

The share of overall intra-industry trade for the group concerned dropped from $38 \%$ to $35 \%$ of total trade (see Figure 1). The comparison of that proportion with those for the other SITC groups indicates that the EU-15 maintained high competitiveness in the commodity group in question (see Figure 2).

The assessment of the dynamics of the competitive position based on the composition of the EU-15 IIT in the group of machinery and transport equipment is not unambiguously favourable. It is confirmed by the results of the IIT index analysis regarding specific types of two-way trade in 2004-2015 (cf. Figure 2). Importantly, there was a fall in the value of GHM indices of the share of HIIT - for horizontal trade (from $10.9 \%$ to $8.2 \%$ ). In the years in question, the horizontal two-way trade of the EU-15 mostly developed with the new EU Member States (a rise by 129.6\%, i.e. by EUR 13.4 billion) and with third countries (respectively: up by $59.1 \%$ and EUR 17 billion). For comparison, the corresponding growth rate of mutual trade within the EU-15 was only $3.1 \%$ (up by EUR 5 billion). The GHM index for VIITh - high quality vertical trade - increased from $12.6 \%$ to $15.2 \%$ of intra-industry trade. Firms from the EU-15 mostly engaged in vertical two-way trade in high quality products with partners from the EU-10 (up by $171.6 \%$, i.e. EUR 31 billion). The respective figures for trade with third countries were as follows: the rate of growth at $103.4 \%$, i.e. by EUR 76 billion, whereas for mutual trade within the EU-15: the rate of growth at $21.0 \%$, i.e. by EUR 40.8 billion.
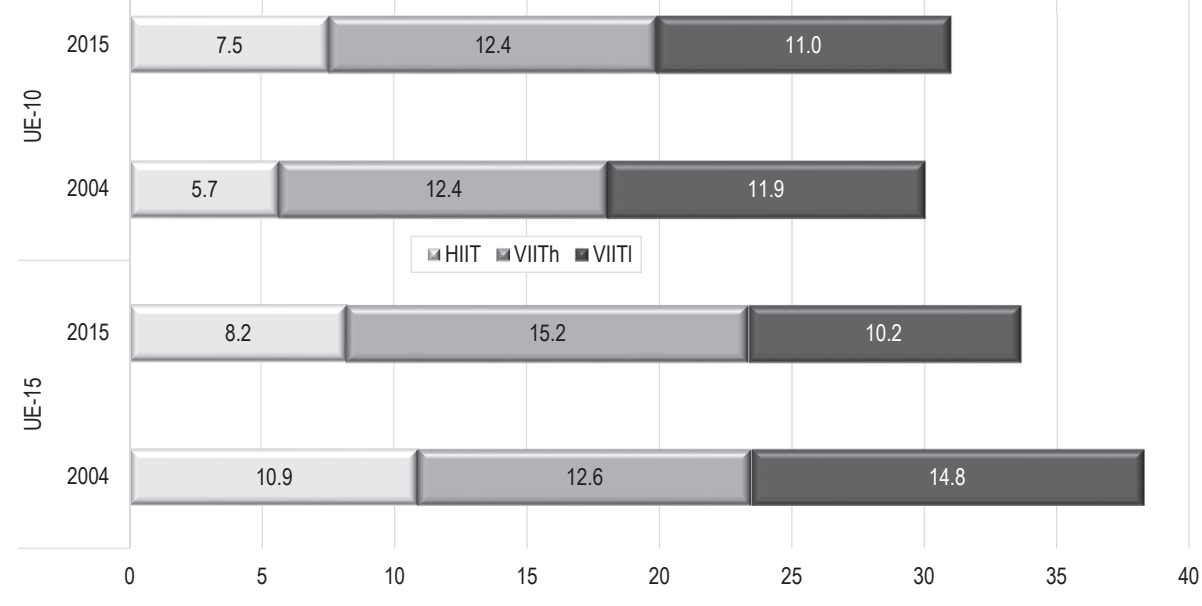

Figure 2. Importance of specific types of intra-industry trade to the EU-10 and the EU-15 in trade in machinery and transport equipment (SITC section 7) in 2004 and 2015 (GHM indices in \%)

Source: Eurostat, EasyComext, http://epp.eurostat.ec.europa.eu/newxtweb [retrieved on 13/03/2017]. Own study. 
The analysis of development trends for intra-industry trade in the group of machinery and transport equipment (SITC section 7) in the EU-15 allows to demonstrate the main trends in the intra-industry competitiveness of the EU-10 in the group in question against the backdrop of the EU-15.

In 2004-2015, products from the SITC commodity group (7) accounted for the largest part of foreign trade in the EU-10 - as in the EU-15. In 2015, machinery and transport equipment represented as much as $43.4 \%$ of the value of total trade in the new EU Member States ${ }^{5}$. In 2004, the respective share was $40.4 \%$. In the period covered, the group concerned gained in importance in the overall trade of the EU-10. It is reflected in the high dynamics of trade - a rise from EUR 178.8 billion to EUR 534.0 billion, i.e. more than threefold growth in the value of imports and exports in the commodity group concerned $^{6}$.

In the period under examination, IIT in machinery and transport equipment was characterised by a significant rise in the share of the EU-10: in 2004 it was 7\%, whereas in 2015 it was already nearly $15 \%$ of two-way trade (cf. Table 1). Not surprisingly, therefore, in 2004-2015 in the intra-industry trade of the new EU Member States the SITC commodity group (7) played an even greater role than in the case of the EU-15. In 2015 , machinery and transport equipment accounted for nearly half $(49.3 \%)$ of the value of the EU-10 two-way trade. In 2004, the respective share was $50.9 \%$. Its trade value jumped from EUR 172.3 billion to EUR 700 billion (by 220\%). However, the growth rate of IIT in the SITC commodity group (7) in comparison with other commodity groups was relatively low (only lower in the case of the SITC commodity group including sections 6 and 8 - other manufactured goods). For the new EU Member States, as in the EU-15, in 2004-2015 the largest growth in intra-industry trade took place in commodity groups other than machinery and transport equipment (which mainly resulted from its low levels in those groups in 2004).

The IIT index in the EU-10 trade in the commodity group in question rose from $30 \%$ in 2004 to $32 \%$ in 2015 (see Figure 1). The comparison with the other SITC groups

\footnotetext{
${ }^{5}$ As regards Poland's largest exporting enterprises, the so-called Polish Business Ambassadors abroad, the ranking of Wprost (http://rankingi.wprost.pl/200-najwiekszych-firm/ retrieved on 23/02/2018) indicated the following operators from the SITC section concerned (7): Remontowa Holding, Solaris, PKP, PESA, Sanok Rubber, Amica.

${ }^{6}$ In the majority of the countries under analysis, a major role in trade, particularly in exports, was played by transport equipment, dominated by products of the automotive industry. After the mid-1990s, the Central European countries, i.e. the Czech Republic, Poland, Romania, Slovakia, Slovenia and Hungary, became integrated into the global chain of automotive production as destinations for foreign capital in the form of foreign direct investment in the automotive sector, largely in motor vehicle assembly plants. The division of production processes into specific stages, frequently located in a number of countries, created trade flows: between plants producing parts and components and the car assembly plant as well as between the assembly plant and the outlet for the cars produced.
} 
indicates that the EU-10 strengthened their intra-industry competitiveness in the commodity group concerned (cf. Table 3 ).

Table 3. Value and structure of merchandise trade by SITC commodity group in the EU-10 and the EU-15 in 2004 and 2015, broken down into total trade and intra-industry trade

\begin{tabular}{|c|c|c|c|c|c|c|c|c|c|}
\hline \multirow{4}{*}{ Partner } & \multirow{4}{*}{ Type } & \multirow{2}{*}{\multicolumn{4}{|c|}{$\begin{array}{c}\text { intra-industry trade } \\
\text { EUR billion }\end{array}$}} & \multicolumn{4}{|c|}{ Dynamics } \\
\hline & & & & & & \multicolumn{2}{|c|}{ EUR billion } & \multicolumn{2}{|c|}{$\%$} \\
\hline & & \multirow{2}{*}{$\begin{array}{c}\text { EU-10 } \\
2004\end{array}$} & \multirow{2}{*}{$\begin{array}{c}\text { EU-10 } \\
2015\end{array}$} & \multirow{2}{*}{$\begin{array}{c}\text { EU-15 } \\
2004\end{array}$} & \multirow{2}{*}{$\begin{array}{c}\text { EU-15 } \\
2015\end{array}$} & EU-10 & EU-15 & EU-10 & EU-15 \\
\hline & & & & & & \multicolumn{2}{|c|}{ 2004-2015 } & \multicolumn{2}{|c|}{ 2004-2015 } \\
\hline \multirow{4}{*}{ EU-15 } & HIIT & 8.2 & 29.4 & 159.7 & 164.6 & 21.1 & 5.0 & 256.6 & 3.1 \\
\hline & VIIThigh & 18.7 & 46.9 & 193.9 & 234.7 & 28.2 & 40.8 & 151.1 & 21.0 \\
\hline & VIITlow & 17.7 & 42.7 & 159.4 & 180.4 & 24.9 & 21.0 & 140.7 & 13.2 \\
\hline & Total & 44.7 & 119.9 & 514.3 & 609.4 & 75.2 & 95.2 & 168.3 & 18.5 \\
\hline \multirow{4}{*}{ EU-10 } & HIIT & 1.0 & 8.9 & 10.3 & 23.8 & 7.9 & 13.4 & 833.7 & 129.6 \\
\hline & VIIThigh & 1.6 & 11.4 & 18.1 & 49.1 & 9.8 & 31.0 & 596.0 & 171.6 \\
\hline & VIITlow & 1.5 & 11.0 & 10.7 & 37.9 & 9.6 & 27.2 & 654.0 & 254.4 \\
\hline & Total & 4.1 & 31.4 & 39.2 & 112.5 & 27.4 & 73.3 & 670.8 & 186.8 \\
\hline \multirow{4}{*}{ Third countries } & HIIT & 0.9 & 1.9 & 28.7 & 45.7 & 1.0 & 17.0 & 110.2 & 59.1 \\
\hline & VIIThigh & 1.9 & 7.8 & 73.4 & 149.4 & 5.9 & 76.0 & 317.9 & 103.4 \\
\hline & VIITlow & 2.1 & 5.3 & 44.0 & 74.2 & 3.1 & 30.3 & 145.9 & 68.9 \\
\hline & Total & 5.0 & 21.0 & 146.7 & 271.9 & 16.0 & 125.2 & 319.7 & 85.3 \\
\hline
\end{tabular}

Source: Eurostat, EasyComext, http://epp.eurostat.ec.europa.eu/newxtweb [retrieved on 13/03/2017]. Own study.

An examination of the dynamics of the competitive position based on analysing the types of IIT in the SITC commodity group (7) allows to positively assess the trends observed for the EU-10 (in contrast to the case of the EU-15). Importantly, in 2004-2015 there was an increase in the GHM indices for horizontal trade (from $5.7 \%$ to $7.5 \%$ of total intra-industry trade within the SITC commodity group (7)). In the EU-10, intraindustry trade in horizontally differentiated products grew the most rapidly within the single European market - in mutual trade (the rate of growth at $833.7 \%$, i.e. by EUR 7.9 billion) and with the EU-15 (up by $256.6 \%$, i.e. EUR 21.1 billion). The respective indicators in trade with non-EU countries were $110.2 \%$ and EUR 1 billion. At the same time, in the EU-10 two-way trade in high quality vertically differentiated products of the SITC commodity group (7) developed the most dynamically in mutual trade (up by $596 \%$, i.e. EUR 9.8 billion) and with third countries (the rate of growth at $317 \%$, i.e. by EUR 5.9 billion). For trade with the EU-15, the growth rate of high quality VIIT was $151.1 \%$ and the trade value went up by EUR 28.2 billion.

In 2004-2015, machinery and transport equipment played the greatest role in intraindustry trade in both the EU-15 and the EU-10. In the period covered, the EU-15 
maintained high intra-industry competitiveness within the commodity group in question ${ }^{7}$. Over the same period, the EU-10 significantly strengthened their competitive position in the group concerned. Importantly, after the enlargement of the European Union the development directions of the most desirable types of two-way trade observed in the new EU Member States were synchronised with the trends characteristic of the EU-15. It indicates similar compositions of intra-industry trade in both integrating economic areas. It also confirms the trend of strengthening intra-industry competitiveness within the SITC commodity group (7) in the single European market.

Changes in the structure by type of intra-industry trade in machinery and equipment in the EU-10 can be regarded as favourable. The rise in the shares of horizontal and high quality vertical IIT indicates that the majority of the countries covered were no longer mere suppliers of primary commodities, unprocessed products or of low-value goods: they increasingly exported semi-finished products and final goods of high quality and significant technology intensity. Those changes can be attributed to the modernisation of the machinery and equipment industry and with the inflow of foreign direct investment to the sector concerned (Czarny, Śledziewska 2009, pp. 92-116). The scale of such developments varied between the states covered, hence the different effects observed (Kawecka-Wyrzykowska, Ambroziak, Molendowski, Polan, 2017, p. 88).

An example illustrating the phenomenon at the enterprise level can be a major involvement of Germany's largest automotive companies in the building of production branches in the new EU Member States. The list of the largest German exporting enterprises includes four concerns from the automotive industry: the Volkswagen Group (VW), Daimler, the BMW Group and Continental ${ }^{8}$. Three of them considerably increased their business operations in the EU-10. In the ranking of the largest firms from Central and Eastern Europe, VW subsidiaries were ranked as follows: $2^{\text {nd }}-$ Škoda Auto A.S. in the Czech Republic, $5^{\text {th }}$ - Volkswagen Slovakia A.S., $6^{\text {th }}$ - Audi Hungaria Motor KFT, $30^{\text {th }}$

\footnotetext{
${ }^{7}$ In a more detailed analysis of the composition of intra-industry trade by type, the section including transport equipment must be treated with particular caution. The section in question comprises goods of varying nature, in terms of production methods and uses of final products. The production of motor vehicles, in particular of passenger cars, was characterised by a high degree of production process fragmentation. On the other hand, processes in the manufacture of railbound vehicles or vessels were distinctly less fragmented. According to theory, the higher the degree of production fragmentation, the greater the possibility of differentiating varieties of goods produced at specific production stages, thus the higher potential for growth in intra-industry trade. The groups of products under examination played different roles in particular countries, which was reflected in the structure of intra-industry trade in type in the SITC commodity group (7). In addition, the structure of intraindustry trade in transport equipment by type was at times distorted for statistical reasons. In certain countries, e.g. in Poland, intra-industry trade included processing activities such as repairs of ships from other countries. A vast majority of such trade was vertical in nature, with the country in which ships were repaired exporting vessels of higher unit values (after repairs) and importing vessels of lower unit values (in need of repair work). For instance, it was observed in trade in ships between Poland and Norway (for more cf. Ambroziak 2013).

${ }^{8}$ Cf. http://www.worldexports.com/germanys-top-exports/ (retrieved on 24/02/2018).
} 
- Volkswagen Poznań Sp. z 0.0. and 39th - Volkswagen Group Polska Sp. z 0.0. In the same ranking, Mercedes-Benz Manufacturing Hungary KFT was ranked $17^{\text {th }}$, whereas Continental Automotive Czech Republic S.R.O. and Continental Barum S.R.O. were ranked $51^{\text {st }}$ and $54^{\text {th }}$ respectively 9 .

\section{Other manufactured goods}

In 2004-2015, the group of other manufactured goods represented the second behind SITC section 7 - most important commodity group in the foreign trade of both the EU-15 and the EU-10. Over the analysed period from 2004 to 2015, however, in the case of both economic areas there was a decrease in the share of the commodity group in question in total trade - from $28.2 \%$ to $26 \%$ in the case of the EU-15, from $34.1 \%$ to $28.5 \%$ for the EU-10 (cf. Table 1). As regards the EU-15, the growth rate of total trade in the SITC commodity group concerned (sections 6 and 8 ) was the lowest among all the group under analysis $-52 \%$. That was also the case for the EU-10, with the growth rate at $132 \%$ (cf. Table 2 ).

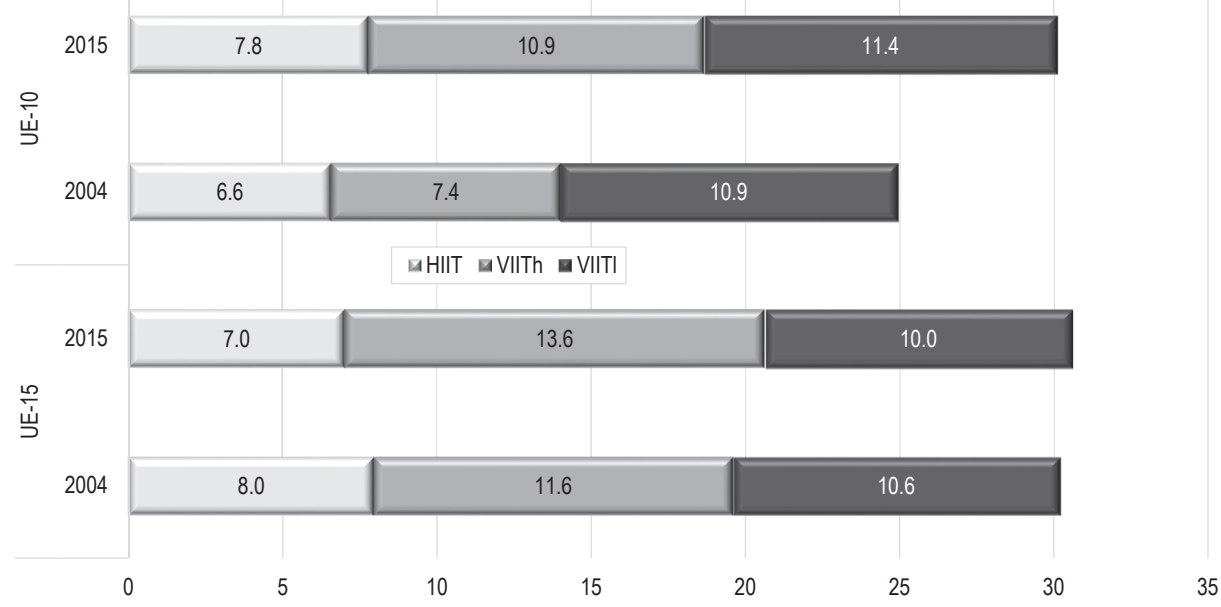

Figure 3. Importance of specific types of intra-industry trade to the EU-10 and the EU-15 in trade in other manufactured goods (SITC sections 6 and 8) in 2004 and 2015 (GHM indices in \%)

Source: Eurostat, EasyComext, http://epp.eurostat.ec.europa.eu/newxtweb [retrieved on 13/03/2017]. Own study.

With regard to the EU-15, in 2015 as much as $27.2 \%$ of intra-industry trade concerned goods included in the SITC commodity group in question (sections 6 and 8). In 2004, the respective share was $27.8 \%$. It means a rise in turnover from EUR 414 billion to EUR 635 billion (by 52\%). Therefore, other manufactured goods constituted

\footnotetext{
${ }^{9}$ Cf. www.coface.pl/Aktualności-i-media/Rankingi-i-konferencje/TOP-500-CEE (retrieved on 24/02/2018).
} 
a significant commodity group for two-way transactions in the EU-15 (cf. Table 1). The Grubel-Lloyd IIT index for the SITC product group in question (6+8) increased from $31 \%$ to $32 \%$ (see Figure 1). For the EU-15, the only commodity groups characterised by greater dynamics of involvement in the intra-industry division of labour were chemicals and machinery and transport equipment.

The result of the analysis of intra-industry trade indices concerning specific types of two-way trade in 2004-2015 (cf. Figure 3) indicate no major improvement of the international competitive position of the EU-15 in the SITC commodity group (6+8). The GHM index for horizontal trade, the most desirable indicator from the point of view of this analysis, dropped from $8 \%$ in 2004 to $7 \%$ in 2015 . As in the case of machinery and transport equipment, in the years covered the horizontal two-way trade of the EU-15 in other manufactured goods mostly developed with the new EU Member States (a rise by $129.6 \%$, i.e. EUR 7.9 billion) and with third countries (respectively: up by $68.8 \%$, i.e. EUR 8.5 billion). The growth rate of mutual horizontal trade within the EU-15 was $22 \%$ (an increase in value by EUR 18.9 billion) over the same period.

The analysed SITC category $(6+8)$ encompasses other products included in section 6 (manufactured goods classified chiefly by material, e.g. leather and leather manufactures, rubber manufactures, cork and wood manufactures, paper manufactures, textile yarn and fabrics, non-metallic mineral manufactures, iron and steel, non-ferrous metals and manufactures of metals) and section 8 (miscellaneous manufactured articles, mostly: prefabricated buildings, various fixtures and fittings; furniture; travel goods; apparel; footwear; professional, scientific and controlling instruments and apparatus; photographic apparatus, equipment and supplies and optical goods). It is a broad category of products, including manufactures of heavy and light industries ${ }^{10}$. Importantly from the point of view of examining the types of intra-industry trade - particularly of high quality vertical trade - that commodity group also comprises articles of apparel and clothing accessories, furniture, footwear, tyres, characterised by strong brands and vital influence of their marketing on the standardisation of consumer demand patterns not only in the single European market but affecting global demand for such products as well. Intra-Community trade in products included in the category in question was also considerably stimulated by the development in the EU's single market of DIY \& Gardening distribution chains (e.g. IKEA, Adeo, Kesko, OBI, Bauhaus, Leroy Merlin, Bricomarche, KIK, Castorama, Praktiker, METRO, REWE). The expansion of such operators, mostly based in the EU-15, in markets of the new EU Member States as well as their key supplier concentration strategies influenced significant intra-Community purchase and sale

\footnotetext{
${ }^{10}$ In the period covered, the greatest contributors to the expansion of Polish exports in the SITC commodity group in question (6+8) included the following enterprises: Impexmetal, Alumetal, Stalprodukt, FAKRO, ZGK Bolesław, Hutmen, Selena, Nicroment, Alchemia, Nowy Styl, BRW, PressGlass, Grupa Kęty, Forte, Stalmet, CCC. Cf. http://rankingi.wprost.pl/200-najwiekszych-firm/ retrieved on: 23/02/2018.
} 
transactions. Bearing in mind the above, it is hardly surprising that in the period covered the share of IIT in high quality vertically differentiated products rose by $2 \mathrm{pps}$ (from $11.6 \%$ to $13.6 \%$ of the total two-way trade of the EU-15). In 2004-2015, that type of intra-industry trade in the EU-15 mostly developed in relations with the new EU Member States (the rate of growth at $108.8 \%$, i.e. by EUR 15.1 billion) and with third countries (up by $82.9 \%$, i.e. EUR 32.6 billion). Cf. Table 4.

Table 4. Dynamics of specific types of the intra-industry trade in other manufactured goods (SITC sections 6 and 8) of the EU-10 and of the EU-15 with major groups of partners in 2004 and $2015(2004=100 \%)$

\begin{tabular}{|c|c|c|c|c|c|c|c|c|c|}
\hline \multirow{4}{*}{ Partner } & \multirow{4}{*}{ Type } & \multirow{2}{*}{\multicolumn{4}{|c|}{$\begin{array}{c}\text { intra-industry trade } \\
\text { EUR billion }\end{array}$}} & \multicolumn{4}{|c|}{ Dynamics } \\
\hline & & & & & & \multicolumn{2}{|c|}{ EUR billion } & \multicolumn{2}{|c|}{$\%$} \\
\hline & & \multirow{2}{*}{$\begin{array}{c}\text { EU-10 } \\
2004\end{array}$} & \multirow{2}{*}{$\begin{array}{c}\text { EU-10 } \\
2015\end{array}$} & \multirow{2}{*}{$\begin{array}{c}E U-15 \\
2004\end{array}$} & \multirow{2}{*}{$\begin{array}{c}\text { EU-15 } \\
2015 \\
\end{array}$} & EU-10 & EU-15 & EU-10 & EU-15 \\
\hline & & & & & & \multicolumn{2}{|c|}{ 2004-2015 } & \multicolumn{2}{|c|}{ 2004-2015 } \\
\hline \multirow{4}{*}{ EU-15 } & HIIT & 7.8 & 17.2 & 86.1 & 105.0 & 9.5 & 18.9 & 121.8 & 22.0 \\
\hline & VIIThigh & 8.3 & 26.4 & 117.7 & 170.3 & 18.1 & 52.6 & 217.5 & 44.7 \\
\hline & VIITlow & 13.5 & 28.3 & 90.8 & 128.1 & 14.8 & 37.4 & 109.6 & 41.2 \\
\hline & Total & 29.7 & 72.1 & 303.8 & 416.0 & 42.4 & 112.2 & 142.9 & 36.9 \\
\hline \multirow{4}{*}{ EU-10 } & HIIT & 1.9 & 8.4 & 6.1 & 14.0 & 6.6 & 7.9 & 354.9 & 129.6 \\
\hline & VIIThigh & 2.1 & 8.7 & 13.9 & 29.0 & 6.5 & 15.1 & 305.0 & 108.8 \\
\hline & VIITlow & 2.2 & 9.0 & 5.6 & 21.3 & 6.9 & 15.7 & 314.6 & 281.9 \\
\hline & Total & 6.2 & 26.2 & 25.7 & 65.0 & 20.0 & 39.3 & 321.8 & 152.6 \\
\hline \multirow{4}{*}{ Third countries } & HIIT & 0.3 & 1.6 & 12.3 & 20.8 & 1.3 & 8.5 & 419.1 & 68.8 \\
\hline & VIIThigh & 0.8 & 3.1 & 39.4 & 72.0 & 2.3 & 32.6 & 290.0 & 82.9 \\
\hline & VIITlow & 0.8 & 2.8 & 24.9 & 49.7 & 2.0 & 24.8 & 252.9 & 99.3 \\
\hline & Total & 1.9 & 7.6 & 84.3 & 154.0 & 5.7 & 69.7 & 295.5 & 82.7 \\
\hline
\end{tabular}

Source: Eurostat, EasyComext, http://epp.eurostat.ec.europa.eu/newxtweb [retrieved on 13/03/2017]. Own study.

In 2015, other manufactured goods accounted for nearly one-third (30.3\%) of the value of the overall intra-industry trade of the EU-10. In 2004, the respective share was $35.8 \%$; the value of IIT jumped from EUR 151 billion to EUR 350.2 billion (by 180\%). Therefore, the growth rate of IIT in the new EU Member States in the SITC commodity group $(6+8)$ as compared to other product groups was the lowest in the period covered.

In 2004-2015, the Grubel-Lloyd index of the share of two-way trade in other manufactured goods went up from $25 \%$ to $30 \%$. Significant increases in the intra-industry trade of the EU-10 in the commodity group in question were observed for all the types of two-way trade. The proportion of horizontal trade augmented from $6.6 \%$ to $7.8 \%$ of total IIT. At the same time, the GHM indices of the share of high quality vertical trade rose from $7.4 \%$ to $10.9 \%$. 
As regards the EU-10, intra-industry trade in horizontally differentiated manufactures included in the SITC commodity group (6+8) showed the most robust growth in relations with third countries (up by $419.1 \%$, i.e. EUR 1.3 billion) and in mutual trade (up by $354.9 \%$, i.e. EUR 6.6 billion). Simultaneously, high quality vertical trade in the EU-10 developed the most dynamically in mutual trade (the rate of growth at $305 \%$, an increase in trade by EUR 6.5 billion) and with third countries (up by 290\%, i.e. EUR 2.3 billion).

\section{Chemicals}

In 2004-2015, SITC section 5 - organic and inorganic chemicals; dyeing, tanning and colouring materials; medicinal and pharmaceutical products; perfume materials; toilet, polishing and cleaning preparations; fertilisers; plastics and other chemical materials and products - represented the third most important group of products in foreign trade, both in the EU-15 and the EU-10. Over the 11 years under analysis, the share of that group went up both in the total trade and in the intra-industry trade of the EU-25. With regard to the EU-15, a rise in two-way trade in chemicals from EUR 230.2 billion to EUR 391.7 billion indicated an increase in the share of the commodity group in question in overall intra-industry trade by $1.5 \mathrm{pps}$ (from $15.5 \%$ to $17 \%$ ). In the case of the EU-10, the growth was even more distinct - the proportion augmented by 3.4 pps (a rise in trade from EUR 6.3 billion to EUR 33 billion) (cf. Table 1).

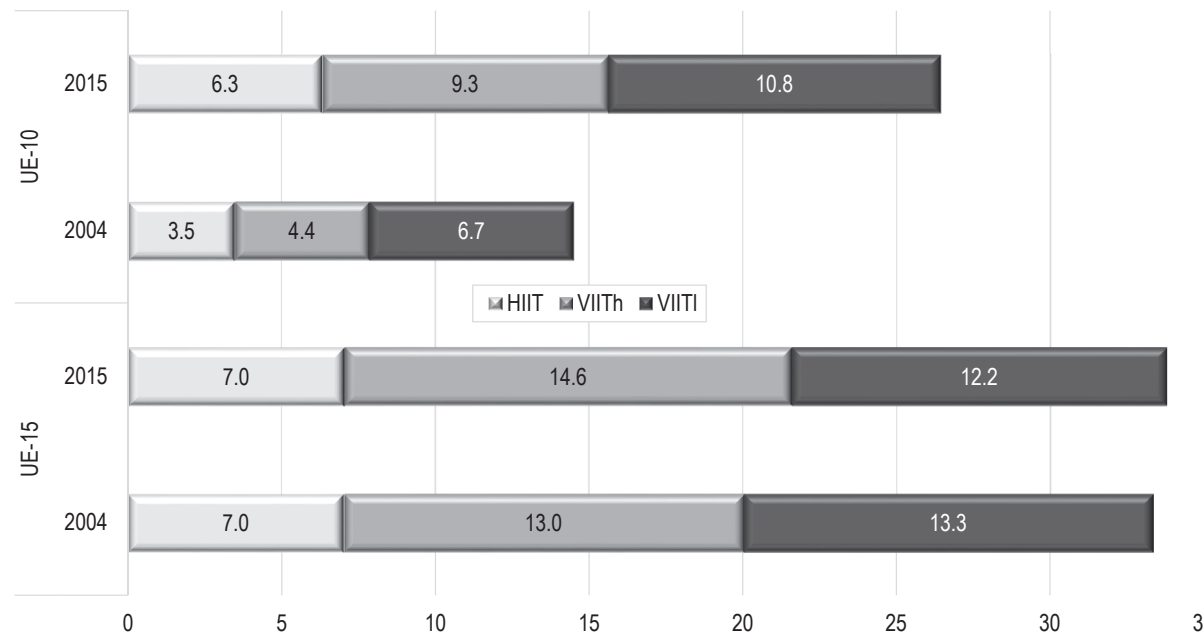

Figure 4. Importance of specific types of intra-industry trade to the EU-10 and the EU-15 in trade in chemicals (SITC section 5) in 2004 and 2015 (GHM indices in \%)

Source: Eurostat, EasyComext, http://epp.eurostat.ec.europa.eu/newxtweb [retrieved on 13/03/2017]. Own study. 
In the EU-15, the Grubel-Lloyd IIT index for the SITC product group (5) went up from $33 \%$ to $34 \%$ (cf. Figure 1). It means that in the period covered the involvement of the EU-15 economies in the intra-industry division of labour within the industry concerned was similar to the proportion of two-way trade in machinery and transport equipment.

The period 2004-2015 saw an improvement in the intra-industry competitive position of the EU-15 in trade in chemicals. It is confirmed by the results of the intra-industry trade index analysis regarding specific types of two-way trade within the SITC commodity group (5) (cf. Figure 4). The GHM index for trade in horizontally differentiated products remained at $7 \%$, whereas the value of trade increased from EUR 48.2 billion to EUR 82.3 billion. As in the case of other categories of manufactured goods (SITC section 7, SITC sections 6 and 8 ), also for chemicals the horizontal two-way trade of the EU-15 grew the most rapidly with the new EU Member States (by $398.7 \%$, i.e. EUR 3.4 billion). The respective growth rate of mutual trade was $73.1 \%$ (up by EUR 29.4 billion), whereas trade with third countries went up by $17.2 \%$ (i.e. EUR 1.2 billion). At the same time, the share of high quality vertical trade rose by $1.6 \mathrm{pps}$ from $\mathrm{GHM}=13.0 \%$ in 2004 to $\mathrm{GHM}=14.6 \%$ in 2015 . That type of trade in the EU-15 developed mostly with the EU-10 and with third countries (cf. Table 5).

Table 5. Dynamics of specific types of the intra-industry trade in chemicals (SITC section 5) of the EU-10 and of the EU-15 with major groups of partners in 2004 and $2015(2004=100 \%)$

\begin{tabular}{|c|c|c|c|c|c|c|c|c|c|}
\hline \multirow{4}{*}{ Partner } & \multirow{4}{*}{ Type } & \multirow{2}{*}{\multicolumn{4}{|c|}{$\begin{array}{c}\text { intra-industry trade } \\
\text { EUR billion }\end{array}$}} & \multicolumn{4}{|c|}{ Dynamics } \\
\hline & & & & & & \multicolumn{2}{|c|}{ EUR billion } & \multicolumn{2}{|c|}{$\%$} \\
\hline & & \multirow{2}{*}{\begin{tabular}{|l|}
$E U-10$ \\
2004 \\
\end{tabular}} & \multirow{2}{*}{$\begin{array}{c}\text { EU-10 } \\
2015\end{array}$} & \multirow{2}{*}{$\begin{array}{c}\mathrm{EU}-15 \\
2004\end{array}$} & \multirow{2}{*}{$\begin{array}{c}\text { EU-15 } \\
2015\end{array}$} & EU-10 & EU-15 & EU-10 & EU-15 \\
\hline & & & & & & \multicolumn{2}{|c|}{ 2004-2015 } & \multicolumn{2}{|c|}{ 2004-2015 } \\
\hline \multirow{4}{*}{ EU-15 } & HIIT & 0.9 & 5.1 & 40.2 & 69.6 & 4.2 & 29.4 & 452.2 & 73.1 \\
\hline & VIIThigh & 1.0 & 7.6 & 69.9 & 121.3 & 6.6 & 51.4 & 636.1 & 73.5 \\
\hline & VIITlow & 2.0 & 9.5 & 73.8 & 100.1 & 7.5 & 26.3 & 378.8 & 35.6 \\
\hline & Total & 3.9 & 22.2 & 184.4 & 292.2 & 18.2 & 107.8 & 462.2 & 58.5 \\
\hline \multirow{4}{*}{ EU-10 } & HIIT & 0.5 & 2.4 & 0.9 & 4.3 & 1.9 & 3.4 & 363.8 & 398.7 \\
\hline & VIIThigh & 0.7 & 3.2 & 1.5 & 7.5 & 2.6 & 6.1 & 372.4 & 416.8 \\
\hline & VIITlow & 0.7 & 3.0 & 0.8 & 7.5 & 2.3 & 6.8 & 336.2 & 883.2 \\
\hline & Total & 1.9 & 8.7 & 3.1 & 19.4 & 6.8 & 16.3 & 356.3 & 526.7 \\
\hline \multirow{4}{*}{ Third countries } & HIIT & 0.1 & 0.4 & 7.1 & 8.3 & 0.3 & 1.2 & 489.1 & 17.2 \\
\hline & VIIThigh & 0.2 & 0.7 & 15.2 & 41.5 & 0.5 & 26.3 & 306.5 & 172.6 \\
\hline & VIITlow & 0.2 & 1.0 & 20.0 & 35.3 & 0.7 & 15.2 & 366.1 & 76.0 \\
\hline & Total & 0.5 & 2.1 & 42.7 & 86.1 & 1.7 & 43.4 & 359.9 & 101.5 \\
\hline
\end{tabular}

Source: Eurostat, EasyComext, http://epp.eurostat.ec.europa.eu/newxtweb [retrieved on 13/03/2017]. Own study. 
In 2015 , chemicals accounted for nearly one-tenth $(9.4 \%)$ of the value of the overall intra-industry trade of the EU-10 11 . In 2004 , the respective share was $6 \%$. The value soared from EUR 43.2 billion to EUR 124.2 billion (by 423\%). In 2004-2015, the Grubel-Lloyd index of the share of two-way trade in chemicals in the new EU Member States increased from $15 \%$ to $27 \%$.

Significant increases in the intra-industry trade of the EU-10 in the group in question were observed for all the types of two-way trade. The proportion of horizontal trade augmented from $3.5 \%$ to $6.3 \%$ of total IIT in that commodity group. At the same time, the GHM indices of the share of high quality vertical trade rose from $4.4 \%$ to $9.3 \%$.

In the EU-10, intra-industry trade in horizontally differentiated chemicals grew the most dynamically in relations with third countries (the rate of growth at $489.1 \%$, i.e. by EUR 0.3 billion) and in trade with the EU-15 (up by $452.2 \%$, i.e. EUR 4.2 billion). At the same time, high quality vertical trade in products of the analysed SITC category (5) in the EU-10 developed the most rapidly in trade with the EU-15 (the rate of growth at $636.1 \%$, an increase in trade by EUR 6.6 billion) and in mutual trade within the EU-10 (up by $372.4 \%$, i.e. EUR 2.6 billion).

\section{Intra-industry trade in manufactured goods broken down into categories based on technology intensity}

In 2015, international trade in manufactures included in SITC section 5, sections 6 and 8 and section 7 represented nearly $80 \%$ of the total merchandise trade of the EU25. With the application of the UNCTAD classification, the groups can be broken down into four categories of products by technology intensity ${ }^{12}$. Analysing such a structure of intra-industry trade is of particular importance to assessing changes in the competitiveness of economies. From the point of view of improving competitiveness, it is more desirable to increase horizontal and high quality vertical two-way trade in manufactured goods characterised by high technology intensities than to focus more on low quality vertical trade in resource-based and labour-intensive products.

The analysis of data presented in Figure 5 allows to conclude that in 2004-2015 total trade and IIT in manufactures in the case of both the EU-10 and the EU-15 mostly developed in the categories of medium- and high-technology products ('MidTech' and 'HighTech' indications respectively).

\footnotetext{
${ }^{11}$ A number of Poland's largest exporting enterprises represented the chemical industry (Boryszew, Grupa Azoty, Ciech, Anwil, Synthos, PCC Exol) and the pharmaceutical sector (TZMO, Grupa Adamed). Cf. http:/l rankingi.wprost.pl/200-najwiekszych-firm/ retrieved on: 23/02/2018.

${ }^{12}$ See http://unctadstat.unctad.org/EN/Classifications.html
} 


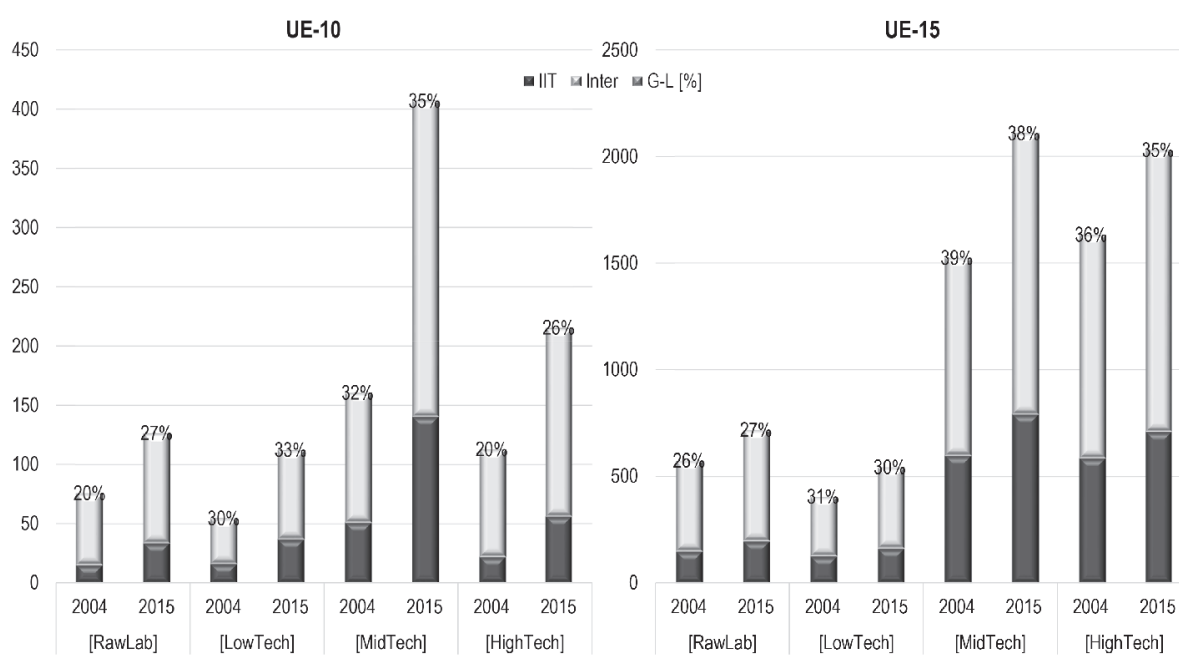

Figure 5. Value of the inter- and intra-industry trade of the EU-10 and of the EU-15 in manufactures broken down by technology intensity [EUR billion] and IIT shares [G-L indices, in \%] in 2004 and 2015

Source: Eurostat, EasyComext, http://epp.eurostat.ec.europa.eu/newxtweb [retrieved on 13/03/2017]. Own study.

In the period covered, there was a considerable improvement in the competitiveness of the EU-10 intra-industry trade. The quality of the two-way trade of that group of countries in high-technology products increased with regard to each of the types of trade under examination. As regards the EU-15, the assessment of changes in the structure is not so unequivocally positive (cf. Figure 6).

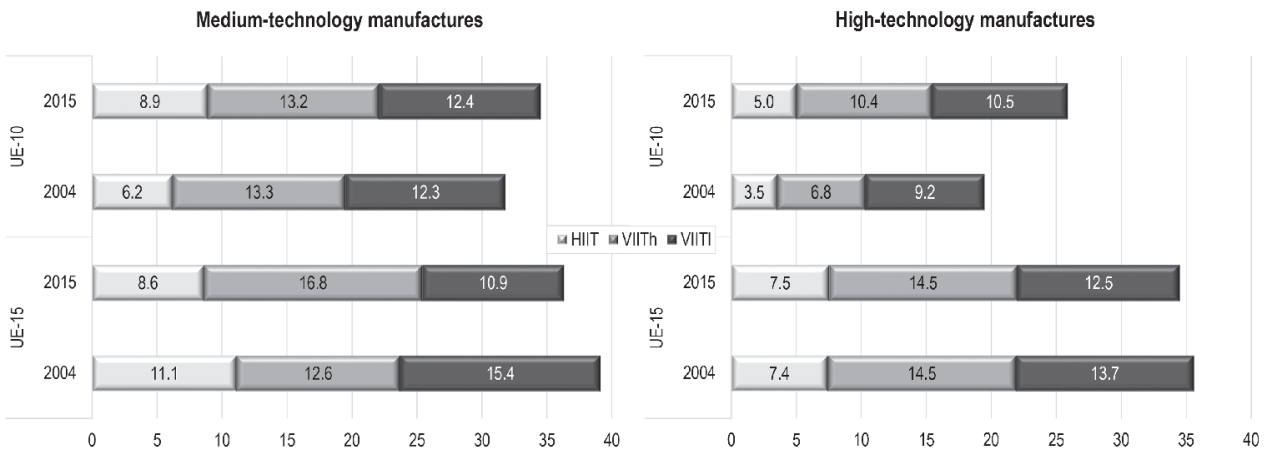

Figure 6. Importance of specific types of intra-industry trade to the EU-10 and the EU-15 in trade in medium- and high-technology manufactures in 2004 and 2015 (GHM indices in \%)

Source: Eurostat, EasyComext, http://epp.eurostat.ec.europa.eu/newxtweb [retrieved on 13/03/2017]. Own study. 
In the EU-10 and the EU-15, trade in high-technology products grew the most dynamically with the EU-10 and third (non-EU-25) countries (see Table 6). It is a significant similarity of changes in the composition of IIT in the single European market in the most important area of intra-industry competitiveness.

Table 6. Dynamics of specific types of the intra-industry trade in manufactures of the EU-10 and of the EU-15 with major groups of partners in 2004 and 2015

\begin{tabular}{|c|c|c|c|c|c|c|c|c|c|}
\hline \multirow{4}{*}{ Partner } & \multirow{4}{*}{ Type } & \multicolumn{4}{|c|}{ Medium-technology goods } & \multicolumn{4}{|c|}{ High-technology goods } \\
\hline & & \multicolumn{2}{|c|}{ EUR billion } & \multicolumn{2}{|c|}{$\%(2004=100 \%)$} & \multicolumn{2}{|c|}{ EUR billion } & \multicolumn{2}{|c|}{$\%(2004=100 \%)$} \\
\hline & & EU-10 & EU-15 & EU-10 & EU-15 & EU-10 & EU-15 & EU-10 & EU-15 \\
\hline & & \multicolumn{2}{|c|}{ 2004-2015 } & \multicolumn{2}{|c|}{ 2004-2015 } & \multicolumn{2}{|c|}{ 2004-2015 } & \multicolumn{2}{|c|}{ 2004-2015 } \\
\hline \multirow{4}{*}{ EU-15 } & HIIT & 19.1 & -11.4 & 230.7 & -8.3 & 4.3 & 20.9 & 150.9 & 21.6 \\
\hline & VIIThigh & 19.8 & 39.9 & 108.3 & 24.7 & 10.2 & 1.7 & 195.1 & 1.0 \\
\hline & VIITlow & 20.4 & -1.9 & 121.0 & -1.3 & 8.2 & 20.1 & 100.4 & 14.2 \\
\hline & Total & 59.3 & 52.1 & 136.3 & 11.6 & 22.8 & 45.2 & 138.9 & 10.7 \\
\hline \multirow{4}{*}{ EU-10 } & HIIT & 5.8 & 12.8 & 534.3 & 132.7 & 2.2 & 2.7 & 262.7 & 71.4 \\
\hline & VIIThigh & 7.6 & 23.0 & 402.0 & 121.6 & 3.3 & 9.3 & 235.9 & 141.0 \\
\hline & VIITlow & 7.3 & 19.5 & 409.5 & 194.0 & 2.8 & 9.8 & 208.7 & 239.3 \\
\hline & Total & 20.7 & 56.9 & 433.8 & 146.8 & 8.4 & 21.9 & 230.0 & 149.7 \\
\hline \multirow{4}{*}{ Third countries } & HIIT & 1.2 & 9.1 & 230.3 & 38.8 & 0.4 & 8.0 & 153.0 & 38.9 \\
\hline & VIIThigh & 5.0 & 59.3 & 392.6 & 116.5 & 1.2 & 16.7 & 117.3 & 21.1 \\
\hline & VIITlow & 3.2 & 15.8 & 284.7 & 44.5 & 1.3 & 30.1 & 158.5 & 60.8 \\
\hline & Total & 9.4 & 84.4 & 319.5 & 76.5 & 3.0 & 56.4 & 136.1 & 37.2 \\
\hline \multirow{4}{*}{ Total } & HIIT & 26.2 & 10.6 & 264.2 & 6.2 & 6.9 & 31.5 & 174.9 & 26.0 \\
\hline & VIIThigh & 32.4 & 161.8 & 150.9 & 84.3 & 14.7 & 57.4 & 192.1 & 24.3 \\
\hline & VIITlow & 30.8 & -6.2 & 156.1 & -2.6 & 12.3 & 30.2 & 119.2 & 13.5 \\
\hline & Total & 89.4 & 193.4 & 174.6 & 32.3 & 34.2 & 123.5 & 153.6 & 21.0 \\
\hline
\end{tabular}

Source: Eurostat, EasyComext, http://epp.eurostat.ec.europa.eu/newxtweb [retrieved on 13/03/2017]. Own study.

As regards the category of medium-technology manufactures, in 2004-2015 the EU10 improved their intra-industry competitiveness to a greater extent than the EU-15. The shares of all the three types of two-way trade increased in the case of the new EU Member States. For the EU-15, growth in proportion was only recorded in the case of trade in horizontally differentiated products (by a mere $0.1 \mathrm{pp}$ ).

\section{Conclusions}

A number of important economic benefits arise from intra-industry trade (IIT). This type of trade gives momentum to international economic linkages. Its growth may facilitate the resolution of various socio-economic development issues. There are significant 
opportunities to deepen the intra-industry division of labour and to improve its structure in the process. Further opening of economies is of key importance to the new EU Member States (EU-10). Moving to a more advanced stage of production internationalisation, i.e. active participation in international economic integration within the European Union, may and should be conducive to improved economic efficiency and increased social well-being (Misala, Pluciński 2000).

Adjustment processes observed in the CEECs in transition were not undisturbed. One drawback was the relatively low intensity, thus specific structure of IIT. Therefore, it is essential to investigate further development of those processes and to make use of such analysis results in seeking more optimal solutions in the real economy and in the institutional and organisational spheres (Molendowski 2007).

The analysis of the main trends in the foreign trade of the EU-10 after the $2004 \mathrm{EU}$ accession indicates increasing similarities between trade patterns in the new EU Member States and the structure characteristic of the EU-15, the convergence of the EU-10 economies and further adjustments to the single market (Polan 2017a).

However, did the process of greater European integration support positive structural effects on the EU-10 economies? An examination of composite indicators (e.g. the Global Competitive Index) does not suggest that after the most extensive enlargements of the European Union in 2004 and 2007 there was an unambiguous enhancement in the economic competitiveness of the EU Member States (Molendowski 2017). The average $\mathrm{GCl}$ value computed for the EU-15 and the EU-10 showed no improvement between 2006 and 2015 - it was 5.1 for the EU-15 and 4.4 for the EU-10. In addition, according to the analysis of the $\mathrm{GCl}$ ranking (arithmetic mean), the competitiveness rank dropped from 21 st to 23 rd for the EU-15 and from 45th to 48th for the EU-10 ${ }^{13}$.

An additional examination of intra-industry competitiveness seems useful at this point. Intra-industry trade may be treated as a competitiveness measure (Molendowski, Polan 2015). The observation of the composition of the EU-15 intra-industry trade and the comparison of the results with trends observed in the EU-10 may help identify advisable development directions of trade models for the EU-10 to fast-track their well-being growth and to narrow their development gap.

The conducted analysis of the intra-industry trade structure in the EU-10 as compared to the respective trends for the EU-15 allowed to demonstrate a significant structural improvement of the intra-industry trade competitiveness of the EU-10 in the period covered. In a number of cases, there was a significant similarity of changes in the composition of IIT in the single European market in the most important areas of intraindustry competitiveness.

\footnotetext{
${ }^{13}$ Own calculations based on The Global Competitive Index Historical Dataset 2007-2016, World Economic Forum, http://reports.weforum.org/global-competitiveness-report-2015-2016
} 
Those trends seem to have mainly resulted from fast adjustments of businesses in the EU-10 to the requirements of the EU's single market. The process appeared to be successful. The goal has been achieved but are the results satisfactory? Does the comparison of well-being effects with those observed in the EU-15 give a sense of satisfying economic outcome? According to the study carried out, intra-industry trade in manufactures in the EU-15 has developed dynamically also outside the single market. It may indicate that the EU-10 should expand their trade relations also with those countries in order to faster catch up with the wealth level of the EU-15.

It seems possible in a longer term. The years after EU accession saw significant development in the technological infrastructure of the new EU Member States. Investments in modern technologies in the EU-10 produced results. The CEECs now have modern, large enterprises, ever-more successful in global markets. Due to dynamic accumulation of knowledge and capital, such companies increasingly rely on their own economic strength rather than only being dependent on operators from Western Europe, the EU-15. In the future, by building solid and global brands and pursuing international marketing strategies they will be able to more effectively influence the demand side purchasing preferences of their customers. It may contribute to more robust growth in trade in vertically differentiated products of high quality and in horizontal intra-industry trade. That, in turn, may be conducive to more intensive convergence in the area of the SEM and increased social well-being in the EU-10.

\section{References}

Ambroziak Ł. (2013). Wpływ bezpośrednich inwestycji zagranicznych na handel wewnątrzgałeziowy państw Grupy Wyszehradzkiej, IBRKK, Warszawa.

Czarny E., Śledziewska K. (2009). Polski handel wewnątrzgałęziowy z Unią Europejską w latach 2000-2007, in: M.A. Weresa (ed.), Polska. Raport o konkurencyjności 2009. Zasoby ludzkie a przewagi konkurencyjne, Oficyna Wydawnicza SGH, Warszawa.

Dyr T., Ziółkowska K. (2017). The intellectual capital as the regions' competitiveness factor, Central European Review of Economics \& Finance 17(1), 33-51.

http://epp.eurostat.ec.europa.eu/newxtweb - a virtual and open database of Eurostat, EasyComext. http://rankingi.wprost.pl/200-najwiekszych-firm/ - a list of Poland's largest exporting enterprises. http://reports.weforum.org/global-competitiveness-report-2015-2016 - source data for analysing competitiveness indices (GCl).

http://www.coface.pl/Aktualności-i-media/Rankingi-i-konferencje/TOP-500-CEE - a list of the largest enterprises of the Central and Eastern European countries.

http://www.worldstopexports.com - a website containing analyses of exports by product group and country. 
Kawecka-Wyrzykowska E., Ambroziak Ł., Molendowski E., Polan W. (2017). Intra-Industry Trade of the New EU Member States. Theory and Empirical Evidence, PWN, Warszawa.

Misala J., Pluciński E.M. (2000). Handel wewnątrzgałęziowy między Polską a Unią Europejską. Teoria i praktyka, Dom Wydawniczy ELIPSA, Warszawa.

Molendowski E. (2007). Liberalizacja wymiany handlowej krajów Europy Środkowowschodniej w okresie transformacji. Ze szczególnym uwzględnieniem doświadczeń krajów CEFTA, Wydawnictwo Uniwersytetu Ekonomicznego w Krakowie, Kraków.

Molendowski E. (2017). Międzynarodowa pozycja konkurencyjna gospodarki - Polska na tle nowych państw członkowskich UE-10 w okresie poakcesyjnym [in:] Nowe kraje członkowskie UE wobec procesów globalizacji. Żródła konkurencyjności, A. Grynia (ed.), Uniwersytet w Białymstoku Wydział Ekonomiczno-Informatyczny w Wilnie, Wilno, pp. 83-96.

Molendowski E., Polan W. (2015). Handel wewnątrzgałęziowy - miernikiem międzynarodowej pozycji konkurencyjnej gospodarek, Zeszyty Naukowe Uniwersytetu Szczecińskiego no. 857, Studia i Prace Wydziału Nauk Ekonomicznych i Zarządzania no. 41 Vol. 1, pp. 11-24.

Polan W. (2015). Główne tendencje w handlu zagranicznym nowych państw członkowskich UE10 po akcesji do Unii Europejskiej, Zeszyty Naukowe „Cracow Review of Economics and Management" №. 10 (946), Uniwersytet Ekonomiczny w Krakowie, Kraków, pp. 21-36.

Polan W. (2017a). Analiza zmian podobieństwa struktur handlu zagranicznego nowych krajów członkowskich Unii Europejskiej w latach 2004-2015 - w kierunku dalszej konwergencji na jednolitym rynku, „Studia i Prace” WNEiZ US no. 49/2, Uniwersytet Szczeciński, Szczecin, pp. 61-74.

Polan W. (2017b). Konkurencyjność wewnątrzgałęziowa, krajów członkowskich Unii Europejskiej w latach 2004-2015 [in:] Nowe kraje członkowskie UE wobec procesów globalizacji. Źródła konkurencyjności, A. Grynia (ed.), Uniwersytet w Białymstoku Wydział EkonomicznoInformatyczny w Wilnie, Wilno, pp. 111-122. 